\title{
Infecciones del torrente circulatorio en pacientes en hemodiálisis
}

\author{
Blood-borne infections in hemodialysis patients
}

Una de las complicaciones más importantes y temidas que enfrentamos con nuestros pacientes de hemodiálisis, tanto en unidades renales como en unidades de cuidados intensivos, son las bacteriemias relacionadas, en su mayoría, con el uso de catéteres intravasculares ( $90 \%$ de las bacteriemias corresponde a pacientes en hemodiálisis). Este hecho se asocia a una elevada mortalidad: es la segunda causa de muerte después de la enfermedad cardiovascular y una causa importante de hospitalización. A pesar de esto, el uso de catéteres temporales y permanentes en pacientes de hemodiálisis no ha disminuido en los últimos años. Incluso, según datos de la Cuenta de Alto Costo, el uso de catéteres de hemodiálisis pasó del 26,5 \%, en el año 2015, al 27,3 \%, en el año 2016 (5.294 pacientes con catéter de los 19.388 pacientes reportados para el año 2016).

Se requieren estudios epidemiológicos grandes en Colombia que permitan conocer el comportamiento de estas infecciones, sus agentes etiológicos y el número de episodios por cada 1.000 días paciente-catéter. Tampoco existen actualmente iniciativas para el desarrollo de guías por parte del Ministerio de Salud sobre este tema. Solo hay esfuerzos locales de algunos prestadores de servicios.

Dentro de las recomendaciones para minimizar el riesgo de infecciones relacionadas con catéteres, se incluye el monitoreo mensual de bacteriemias en pacientes de hemodiálisis, técnica estéril en la esterilización previa a la manipulación de los catéteres en diálisis y el registro de las tasas de infecciones (las cuales deben ser menores a 1,6 episodios por cada 1.000 días catéter — para catéteres tunelizados-y menos de 4,6 episodios por cada 1.000 días catéter — para catéteres transitorios-).

La experticia del médico es fundamental para evitar complicaciones durante su implantación de estos elementos. Algunos autores recomiendan que el nefrólogo, en su etapa de formación, debería implantar al menos 50 catéteres, y continuar con una media de 30 catéteres anuales para mantener la experticia. Estos catéteres deben ser implantados idealmente mediante guía ecográfica.

La educación hacia el paciente es fundamental para disminuir la tasa de infecciones. Esto incluye cuidados del acceso vascular, higiene de manos, riesgos asociados al catéter vascular, reconocimiento temprano de signos de infección, profilaxis del orificio de salida del catéter con antibióticos tópicos, entre otros. Sin embargo, la intervención principal es poder reducir el número de catéteres vasculares, implementando la confección de accesos vasculares definitivos en los pacientes antes del ingreso a terapia, medida que no ha sido posible lograr por parte de algunos aseguradores.

De manera adicional a las bacteriemias asociadas con el catéter, se debe prestar atención a las bacteriemias generadas por gérmenes poco usuales, muchas veces asociados a la contaminación de insumos relacionados con la terapia de hemodiálisis (entre los que se encuentran soluciones de heparina, agua destilada, líneas de circuitos, plantas de agua, etc.). Estos gérmenes tienen un enfoque epidemiológico diferente y se debe tener claridad en su acercamiento diagnóstico, para proceder de manera adecuada.

En resumen, las infecciones del torrente circulatorio en pacientes en terapias de hemodiálisis son una complicación seria asociada a una elevada mortalidad y morbilidad. Esto obliga a implementar, por parte 
de la Asociación Colombiana de Nefrología y el Ministerio de Salud y Protección Social, guías para la prevención y el manejo de esta patología, tanto en nuestras unidades renales como en las unidades de cuidado intensivo. Además, implica promover entre los aseguradores la confección temprana de fístulas arteriovenosas en los pacientes sometidos a hemodiálisis. Estas medidas ayudarán a disminuir, en gran medida, la carga de morbimortalidad relacionada y a disminuir los costos al sistema de salud.

Rafael Alberto Gómez, ragomez1959@gmail.com

Internista Nefrólogo

Asocolnef 